persisted, and he began to expectorate blood-stained sputum. The tonsils were still greatly enlarged and covered by a yellowish exudate. Sputum examination for tubercle bacilli was negative.

Blood culture on Sept.. 2 gave a good growth of Staph. pyogenes (confirmed two days later, when another good growth was obtained). The organism had the following characteristics: a smooth moderately pigmented strain of Staph. pyogenes, non-haemolytic, coagulasepositive; penicillin sensitivity equal to that of the standard "Oxford" strain. It was now clear that the patient had a general septicaemia, and in spite of having received $12 \mathrm{~g}$. of sulphanilamide and $25 \mathrm{~g}$. of sulphathiazole he was getting steadily worse. Sulphathiazole treatment was stopped, and at 22.00 hours penicillin was given instead, in doses of 16,666 units; by intramuscular injection every three hours. The temperature at 22.00 hours was $102^{\circ} \mathrm{F}$., and the pulse rate 110 a minute. No pathogens were obtained from culture of a throat swab. The total white cell count was still relatively low considering the nature of the infection-namely, 6,800 per c.mm., with $50 \%$ polymorphs, $27 \%$ small lymphocytes, $19 \%$ large lymphocytes, and $4 \%$ monocytes. On Sept. 3 and 4 a slight lowering of the temperature and some improvement in his general condition were apparent. On the 5th the temperature dropped to normal and was accompanied by a striking improvement in the patient's general condition and in the local appearance of the throat. The spleen was no longer palpable and the pleural friction rub could not be heard.

Subsequent Progress. - There was a rise of temperature to $100^{\circ} \mathrm{F}$. on Sept. 6 and 7 and to $99^{\circ} \mathrm{F}$. on Sept. 9 and 10, but subsequently the temperature and pulse rate remained at normal levels. Penicillin was discontinued on Sept. 11, as the patient had now received $1,133,288$ units. By this time all clinical evidence of septicaemia had gone and the appearance of the throat was normal. He continued to make an uneventful recovery, with no residual signs of disease in any system, and on Sept. 20 was evacuated to the United Kingdom for a period of convalescence.

\section{Comment on Case II}

This was a case of Staph. pyogenes septicaemia associated with acute tonsillitis. The patient's resistance against the infection was poor, as was evidenced by a serious deterioration in his clinical condition and by the unsatisfactory white blood cell response. Treatment with $12 \mathrm{~g}$. of sulphanilamide followed by $25 \mathrm{~g}$. of sulphathiazole failed to produce any improvement in the local tonsillar infection or in the general condition of the patient. Penicillin was administered at a critical stage of the illness, and within 56 hours was followed by a dramatic improvement and, a few days later, by a complete and uncomplicated recovery.

\section{Summary}

The above two cases present encouraging features in the treatment of Staph. pyogenes septicaemia with penicillin. In the first case the favourable result was probably assisted by sulphapyridine therapy, but in the second case sulphanilamide and sulphathiazole each failed to produce any improvement in the condition. It is felt that these results may encourage others to employ and observe the effect of penicillin therapy in similar cases.

We wish to thank Col. F. G. Flood, M.C., officer commanding the military hospital, for permission to publish this report.

The 150th annual report by the Managers of Glasgow Royal Infirmary, for the year 1944, shows that a very large volume of work was done for the sick and injured from all parts of Britain, including a great many Service cases treated in the wards. For a long time wards have been set aside for the treatment of burns, and more of these injuries have been dealt with at the Glasgow Royal Infirmary than at any other hospital in the British Isles. In view of the need for further research on various aspects of the treatment of burns, the Medical Research Council, in agreement with the managers of the Infirmary, decided to appoint a junior surgeon to give whole-time assistance to Mr. A. M. Clark, who has been in charge of the burns wards for several years, and to establish a laboratory team to survey the problem along with other members of the staff. During last year 318 patients suffering from burns and scalds were admitted. The outstanding features were the greatly reduced death rate $-5.6 \%$ - and the elimination to a very large extent of streptococcal infection, the main source of trouble in burns. All out-patients with burn injuries are now treated in the Unit; they number about a thousand a year. During 1944 the Infirmary received a very considerable supply of penicillin for the treatment of military and civilian cases. Large supplies were distributed to other hospitals in Glasgow, Lanarkshire, Stirlingshire, and Renfrewshire, and the Infirmary is not only a distributive centre but an advisory centre for the use of penicillin.

\section{LOCAL PENICILLIN THERAPY IN OPHTHALMIA NEONATORUM*}

\author{
ARNOLD SORSBY, M.D., F.R.C.S. \\ (White Oak (L.C.C.) Hospital, Swanley)
}

In an earlier communication (Sorsby and Hoffa, 1945) an account was given of the use of penicillin for local therapy in 47 cases of ophthalmia neonatorum. It was shown that consistent results could be obtained when drops in a concentration of not less than 2,500 units per c.cm. were used; of 22 cases so treated 21 recovered, against only 3 out of 8,4 out of 7 , and 6 out of 10 treated with penicillin in concentrations of $500,1,000$, and 1,500 units respectively. The gratifying results obtained with penicillin in adequate concentration had been achieved by instilling one drop of the solution at half-hourly intervals for 3 hours, then hourly for 24 hours, and 2-hourly subsequently. None of these 21 successfully treated cases took longer than 100 hours to show a clinical cure, and in 6 cases clinical cure was obtained within 3 to 24 hours. It was indicated that all the common causal organisms of ophthalmia neonatorum, including the virus of inclusion blennorrhoea, appeared to respond to penicillin, though perhaps to varying degrees, diphtheroid bacilli probably being the most resistant.

\section{A Further Series of 38 Cases}

Like the last 22 cases in the previous series these 38 new cases have all been treated with penicillin in a concentration of 2,500 units per c.cm., but the frequency of instillation has been different : at longer intervals in 13 and at shorter intervals in 25 cases.

(a) Thirteen cases treated with drops of penicillin at intervals of 1 hour for 6 hours, then 2-hourly for 24 hours, and subsequently at 3-hourly intervals.-All these responded well, but one case relapsed after 24 hours and another after 5 days (both of these being finally cleared by a course of sulphamezathine for 5 days and 2 days respectively). The clinical details on these 13 cases are summarized in Tables I and II.

TABLE I.-Time taken for Clinical Cure: in Relation to Severity and Distribution of the Affection

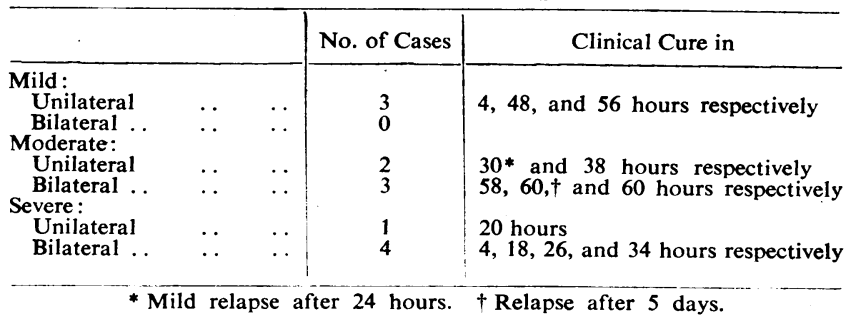

TABLE II.-Time taken for Clinical Cure: in Relation to Causal Organism and Severity of the Affection

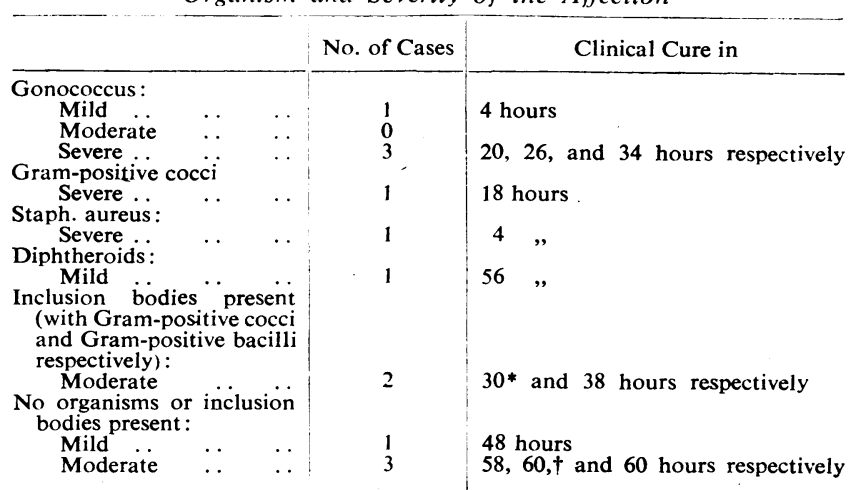

* Mild relapse after 24 hours. Inclusion bodies were also present in scrapings from the mother's cervix.

+Relapse after 5 days. The culture had shown the presence of Ps. pyocyanea, probably a contaminant.

These results do not appear to be substantially different from those obtained in the 22 cases treated at more frequent intervals.

* A report to the Penicillin Clinical Trials Committee of the Medical Research Council. 
(b) Twenty-five cases treated with drops of penicillin initially at intervals of 5 minutes, then half-hourly, and subsequently hourly, followed by 2-hourly intervals. - This unusual procedure requires some explanation. In the previous communication it was reported that when penicillin is used at half-hourly intervals irrigation was generally required before the first 12 applications of drops-i.e., for the first 6 hours of treatment. As drops are washed out of the conjunctival sac within a matter of minutes it was thought desirable to instil penicillin at 5-minute intervals. It was then found that no further irrigation was needed beyond the first one carried out before instilling the penicillin, for all tendency to the formation of pus was rapidly suppressed. When all discharge had ceased penicillin was continued at halfhourly intervals till the eye was dry; thereafter it was instilled hourly for 12 hours and 2-hourly for a further 24 hours. In this series 2 cases showed a distinctly poor response. One was a case of moderate bilateral gonococcal ophthalmia in a premature baby. Sulphamezathine treatment cleared the eyes within 3 days, only to relapse after 13 days and to be cleared finally by a second course of this sulphonamide. The second case was also of moderate severity; diphtheroids were present in the smear, but the culture was negative. This case responded well to sulphamezathine within 4 days.

The clinical details of this group of cases are shown in the following summary tables (III and IV).

TABLE III.-Time taken for Clinical Cure: in Relation to Severity and Distribution of the Affection

\begin{tabular}{|c|c|c|c|c|}
\hline & & & No. of Cases & Clinical Cure in \\
\hline $\begin{array}{l}\text { Mild: } \\
\text { Unilateral } \\
\text { Bilateral ... }\end{array}$ & : & . & $\begin{array}{l}3 \\
3\end{array}$ & $\begin{array}{l}3,6 \text {, and } 21 \text { hours respectively } \\
25 \text { minutes, } 1 \frac{1}{2} \text {, and, } 16 \text { hours } \\
\text { respectively }\end{array}$ \\
\hline $\begin{array}{l}\text { Moderate: } \\
\text { Unilateral } \\
\text { Bilateral ... }\end{array}$ & $\therefore$ & $\because$ & 12 & $\begin{array}{l}22 \text { hours* } \\
3,+3 \frac{1}{k}, 3 \frac{1}{4}, 5 \frac{3}{4}, 6 \frac{1}{3}, 7,11 \frac{1}{2}, \ddagger 13 \frac{1}{2}, \pm \text {, } \\
33, \text {, and } 38 \text { hours respec- } \\
\text { tively, with } 2 \text { further cases } \\
\text { showing no response }\end{array}$ \\
\hline $\begin{array}{l}\text { Severe: } \\
\text { Unilateral } \\
\text { Bilateral }\end{array}$ & $\because$ & :. & $\begin{array}{l}0 \\
6\end{array}$ & $\begin{array}{l}\text { 4, } 10,10,101,16 \text {, and } 16 \frac{1}{2} \| \text { hours } \\
\text { respectively }\end{array}$ \\
\hline
\end{tabular}

TABLE IV.-Time taken for Clinical Cure: in Relation to Causal Organism and Severity of the Affection

\begin{tabular}{|c|c|c|}
\hline & No. of Cases & Clinical Cure in \\
\hline Gonococcus: & & \\
\hline & 1 & $1 \frac{1}{2}$ hours \\
\hline $\begin{array}{l}\text { Moderate } \\
\text { Severe ... }\end{array}$ & $\begin{array}{l}1 \\
3\end{array}$ & $\begin{array}{l}\text { No response } \\
4,10 \text {, and } 101 \text { hours respectively }\end{array}$ \\
\hline $\begin{array}{l}\text { Staph. aureus: } \\
\text { Mild }\end{array}$ & & 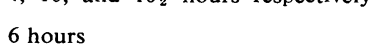 \\
\hline \begin{tabular}{lll} 
Moderate & $\cdots$ & \\
\hdashline
\end{tabular} & 5 & 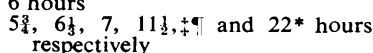 \\
\hline $\begin{array}{ccc}\text { Severe } & \ldots & \\
\text { Diphtheroids: } & & \end{array}$ & 2 & 10 and $16 \frac{1}{2} \|$ hours respectively \\
\hline $\begin{array}{l}\text { Moderate .. } \\
\text { Haemolytic streptococcus: }\end{array}$ & 3 & 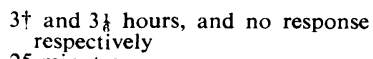 \\
\hline $\begin{array}{l}\text { Mild } \\
\text { Gram-neg. diplococcus: }\end{array}$ & 1 & 25 minutes \\
\hline $\begin{array}{l}\text { Moderate } \\
\text { Friedländer's bacililus: }\end{array}$ & 1 & 33 hoursई \\
\hline $\begin{array}{l}\text { Mild } \\
\text { Morax-Axenfeld bacillus: }\end{array}$ & 1 & $16 \quad$, \\
\hline $\begin{array}{l}\text { Severe ... } \\
\text { No organisms or inclusion }\end{array}$ & 1 & 16 \\
\hline $\begin{array}{l}\text { bodies: } \\
\text { Moderate } \\
\text { nclusion bodies p present } \\
\text { without organisms: }\end{array}$ & 1 & $13 ! "$ \\
\hline $\begin{array}{ccc}\text { without organisms: } & \\
\text { Mild } \ldots & \ldots & \ldots \\
\text { Moderate } & \ldots .\end{array}$ & 1 & $\begin{array}{ll}21 & , \\
38 & ,\end{array}$ \\
\hline $\begin{array}{l}\text { Inclusion bodies present } \\
\text { with organisms (diph- } \\
\text { theroids and Gram-posi- } \\
\text { tive cocci respectively): }\end{array}$ & & - \\
\hline $\begin{array}{lll}\text { Mild } & & \\
\text { Moderate } & . & .\end{array}$ & $\begin{array}{l}1 \\
1\end{array}$ & $-3 \frac{3}{4} \quad ”$ \\
\hline
\end{tabular}

\section{Footnotes to Tables III and IV}

* Relapsed after 24 hours. A second course of penicillin brought about a clinical cure in 8 hours, only to relapse again. Finally cleared by sulphamezathine in 3 days.

$\dagger$ Mild relapse; cleared by a further course in 4 hours.

$¥$ Relapse 5 days later. Sulphamezathine for 68 hours; baby removed against advice with eyes not quite clear.

$\S$ Mild relapse after 6 days. Cleared by further course of penicillin in 41 hours.

II Mild relapse 4 days later. Cleared by a further course in $2 \frac{1}{2}$ hours.

- Inclusion bodies were present in scrapings from the mother's cervix.
This group of 25 cases therefore contains 2 that showed no response to-intensive penicillin therapy and no fewer than 5 which showed initial clinical cure only to be followed by a relapse, which, however, was cleared in 3 out of the 5 cases by a second course of penicillin, suggesting that too early suspension of treatment rather than inefficacy of penicillin was responsible for these partial failures. In contrast to these 2 total and 5 partial failures the remaining 18 cases showed distinctly gratifying results, the time taken for clinical cure being 38 hours at the longest and 25 minutes at the best, with an average of just under 10 hours. The following summary table (V) brings out the essential features:

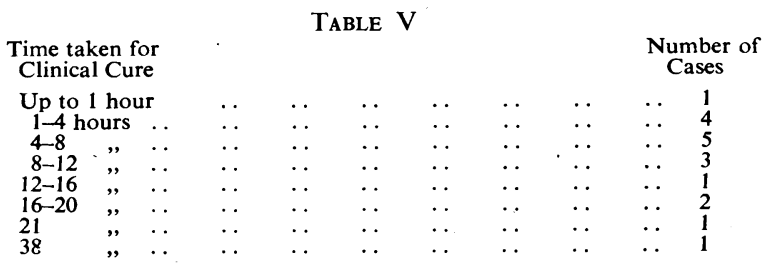

The 5 cases that relapsed had initially showed clinical cure in $3,11 \frac{1}{2}, 16 \frac{1}{2}, 22$, and 33 hours respectively; the 2 cases that had failed to respond had been treated for 40 and 72 hours respectively.

So far as the time taken for clinical cure is concerned, these 18 successful cases (out of 25 ) compare favourably with the 20 comparable cases (out of 22) and the 11 (out of 13) treated by the same concentration of penicillin but less intensively. The comparative figures in Table VI show this clearly:

TABLE VI.-Penicillin Drops in Concentration of 2,500 Units

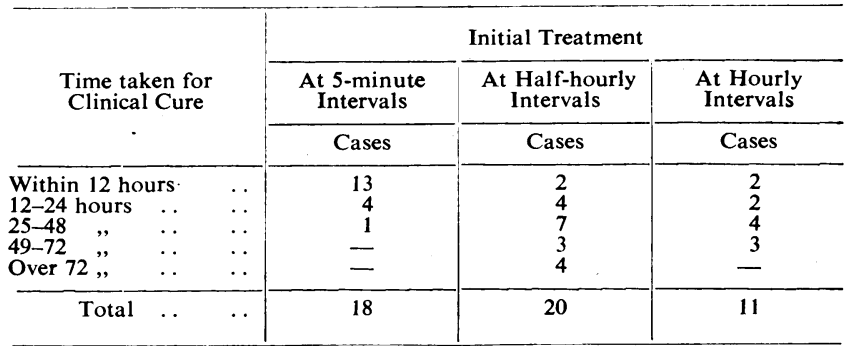

Average time per case : 10,44 , and 33 hours in the three series respectively.

It would therefore appear that intensive penicillin therapy (at 5-minute intervals) reduced the time taken for a clinical cure to one-third or one-quarter of that required when this drug is applied at hourly or half-hourly intervals.

Rapidity of Clinical Cure in Relation to Severity of Affection

No fine distinctions as to any difference in response by heavy and less heavy infections can be drawn from the limited material so far available. There is nothing to suggest that clinically

TABLE VII

\begin{tabular}{|c|c|c|c|}
\hline & \multicolumn{3}{|c|}{ Initial Treatment } \\
\hline & $\begin{array}{l}\text { At } 5 \text {-minute } \\
\text { Intervals } \\
\text { (25 Cases) }\end{array}$ & $\begin{array}{l}\text { At Half-hourly } \\
\text { Intervals } \\
\text { (22 Cases) }\end{array}$ & $\begin{array}{l}\text { At Hourly } \\
\text { Intervals } \\
\text { (13 Cases) }\end{array}$ \\
\hline Mild & $\begin{array}{l}6 \text { cases: clinical } \\
\text { cure in } 25 \text { min- } \\
\text { utes to } 21 \text { hours } \\
\text { Average: } 8 \text { hours } \\
\text { No failures } \\
\text { No relapses }\end{array}$ & $\begin{array}{l}5 \text { cases: clinical } \\
\text { cure in } 7 \text { to } 78 \\
\text { hours } \\
\text { Average: } 51 \text { hours } \\
\text { No failures } \\
\text { No relapses }\end{array}$ & $\begin{array}{l}3 \text { cases: clinical } \\
\text { cure in } 4 \text { to } 56 \\
\text { hours } \\
\text { Average: } 36 \text { hours } \\
\text { No failures } \\
\text { No relapses }\end{array}$ \\
\hline Moderate & $\begin{array}{l}13 \text { cases: clinical } \\
\text { cure in } 3 \text { to } 38 \\
\text { hours } \\
\text { Average (of } 11 \\
\text { cases): } 13 \text { hours } \\
\text { Two failures } \\
\text { Four relapses }\end{array}$ & $\begin{array}{l}11 \text { cases: clinical } \\
\text { cure in } 3 \text { to } 100 \\
\text { hours } \\
\text { Average: } 46 \text { hours } \\
\text { No failures } \\
\text { No relapses }\end{array}$ & $\begin{array}{l}5 \text { cases: clinical } \\
\text { cure in } 30 \text { to } 60 \\
\text { hours } \\
\text { Average: } 41 \text { hours } \\
\text { No failures } \\
\text { Two relapses }\end{array}$ \\
\hline Severe & $\begin{array}{l}6 \text { cases: clinical } \\
\text { cure in } 4 \text { to } 16 \frac{1}{2} \\
\text { hours } \\
\text { Average: } 11 \text { hours } \\
\text { No failures } \\
\text { One relapse }\end{array}$ & $\begin{array}{l}6 \text { cases: clinical } \\
\text { cure in } 36 \text { to } 40 \\
\text { hours } \\
\text { Average (of } 5 \\
\text { cases): } 37 \text { hours } \\
\text { One failure } \\
\text { No relapses }\end{array}$ & $\begin{array}{l}5 \text { cases: clinical } \\
\text { cure in } 4 \text { to } 34 \\
\text { hours } \\
\text { Average: } 16 \text { hours } \\
\text { No failures } \\
\text { No relapses }\end{array}$ \\
\hline
\end{tabular}


severe cases respond less readily. In fact, in the present series the troublesome cases were almost confined to the group regarded as moderate; the 2 cases that gave no response to penicillin and 6 of the 7 cases that showed relapse were all initially cases of moderate severity. The summary of results given in Table VII, which includes the series of 22 comparable cases previously reported, brings out the salient features.

\section{Efficacy in Relation to Causal Organisms}

The following summary table of aetiological types (Table VIII) brings out the time taken to achieve clinical cure in the successfully treated cases and the number of failures and of relapses in each group. The table deals with the 38 cases recorded here and the 22 previously reported.

TABLE VIII

\begin{tabular}{|c|c|c|c|}
\hline & & Initial Treatment & \\
\hline & $\begin{array}{l}\text { At 5-minute } \\
\text { Intervals } \\
\text { (25 Cases) }\end{array}$ & $\begin{array}{l}\text { At Half-hourly } \\
\text { Intervals } \\
\text { (22 Cases) }\end{array}$ & $\begin{array}{l}\text { At Hourly } \\
\text { Intervals } \\
\text { (13 Cases) }\end{array}$ \\
\hline Gonococcus & $\begin{array}{l}5 \text { cases: } 11 \text { to } 10 \frac{1}{2} \\
\text { hours } \\
\text { Average (of } 4 \\
\text { cases): } 7 \frac{1}{2} \text { hours } \\
\text { One failure } \\
\text { No relapses }\end{array}$ & $\begin{array}{l}5 \text { cases: } 24 \text { to } 40 \\
\text { hours } \\
\text { A verage (of } 4^{*} \\
\text { cases): } 35 \text { hours } \\
\text { No failures } \\
\text { No relapses }\end{array}$ & $\begin{array}{l}4 \text { cases: } 4 \text { to } 34 \\
\text { hours } \\
\text { Average: } 21 \text { hours } \\
\text { No failures } \\
\text { No relapses }\end{array}$ \\
\hline Staph. aureus & $\begin{array}{l}8 \text { cases: } 59 \text { to } 22 \\
\text { hours } \\
\text { Average: } 10_{2}^{1} \mathrm{hrs} \text {. } \\
\text { No failures } \\
\text { Three relapses }\end{array}$ & $\begin{array}{l}5 \text { cases: } 3 \text { to } 60 \\
\text { hours } \\
\text { Average: } 20 \text { hours } \\
\text { No failures } \\
\text { No relapses }\end{array}$ & $\begin{array}{l}1 \text { case: } 4 \text { hours } \\
\text { No failures } \\
\text { No relapses }\end{array}$ \\
\hline Staph. albus & - & $\begin{array}{l}4 \text { cases: } 27 \text { to } 43 \\
\text { hours } \\
\text { Average: } 37 \text { hours } \\
\text { No failures } \\
\text { No relapses }\end{array}$ & - \\
\hline Diphtheroids & $\begin{array}{l}3 \text { cases: } 3 \text { and } 31 \\
\text { hours respec- } \\
\text { tively (in } 2 \text { cases) } \\
\text { One failure } \\
\text { One relapse }\end{array}$ & $\begin{array}{l}4 \text { cases: } 50 \text { to } 100 \\
\text { hours } \\
\text { Average (of } 3 \\
\text { cases): } 83 \text { hours } \\
\text { One failure } \\
\text { No relapses }\end{array}$ & $\begin{array}{l}1 \text { case: } 56 \text { hours } \\
\text { No failure } \\
\text { No relapse }\end{array}$ \\
\hline $\begin{array}{l}\text { Haemolytic } \\
\text { streptococcus }\end{array}$ & $\begin{array}{l}1 \text { case: } 25 \text { mins. } \\
\text { No failure } \\
\text { No relapse }\end{array}$ & & \\
\hline $\begin{array}{l}\text { Gram-negative } \\
\text { diplococci }\end{array}$ & $\begin{array}{l}1 \text { case: } 33 \text { hours } \\
\text { No failure } \\
\text { Relapse }\end{array}$ & & \\
\hline $\begin{array}{l}\text { Friedländer's } \\
\text { bacillus }\end{array}$ & $\begin{array}{l}1 \text { case: } 16 \text { hours } \\
\text { No failure } \\
\text { No relapse }\end{array}$ & - & - \\
\hline $\begin{array}{l}\text { Morax- } \\
\text { Axenfeld } \\
\text { bacillus }\end{array}$ & $\begin{array}{l}1 \text { case: } 16 \text { hours } \\
\text { No failure } \\
\text { No relapse }\end{array}$ & . & \\
\hline $\begin{array}{l}\text { Gram-positive } \\
\text { cocci }\end{array}$ & - & - & $\begin{array}{l}1 \text { case: } 18 \text { hours } \\
\text { No failure } \\
\text { No relapse }\end{array}$ \\
\hline $\begin{array}{l}\text { No organisms } \\
\text { or inclusion } \\
\text { bodies }\end{array}$ & $\begin{array}{l}1 \text { case: } 13 \frac{1}{2} \text { hours } \\
\text { No failure } \\
\text { No relapse }\end{array}$ & $\begin{array}{l}2 \text { cases: } 12 \text { and } 70 \\
\text { hqurs respectively } \\
\text { No failures } \\
\text { No relapses }\end{array}$ & $\begin{array}{l}4 \text { cases: } 48 \text { to } 60 \\
\text { hours } \\
\text { Average: } 57 \text { hours } \\
\text { No failures } \\
\text { One relapse }\end{array}$ \\
\hline $\begin{array}{l}\text { Virus presumed } \\
\text { from presence } \\
\text { of inclusion } \\
\text { bodies }\end{array}$ & $\begin{array}{l}4 \text { cases: } 3 \text { to } 38 \\
\text { hours } \\
\text { Average: } 16 \text { hours } \\
\text { No failures } \\
\text { No relapses }\end{array}$ & $\begin{array}{l}2 \text { cases: } 78 \text { and } 100 \\
\text { hours respectively } \\
\text { Average: } 89 \text { hours } \\
\text { No failures } \\
\text { No relapses }\end{array}$ & $\begin{array}{l}2 \text { cases: } 30 \text { and } 38 \\
\text { hours respectively } \\
\text { No failures } \\
\text { One relapse }\end{array}$ \\
\hline
\end{tabular}

* One case omitted, as the complication of corneal ulcer-present on admission -delayed a return to normal.

In this total of 60 cases there were therefore 1 failure in a series of 14 cases showing the gonococcus and 2 failures in a series of 8 cases showing diphtheroids; there were no failures in the 14 cases due to Staph. aureus and in the 4 showing Staph. albus, while the single cases due to Str. haemolyticus, Friedländer's bacillus, Morax-Axenfeld bacillus, Gram-negative diplococci, and Gram-positive cocci all responded. It would therefore seem that all the common causal organisms of ophthalmia neonatorum respond to penicillin therapy; no real significance can be attached to the 3 failures ( 1 gonococcus and 2 diphtheroids) in view of the satisfactory response in other (and more) cases of this type. It is also noteworthy that no failures were seen in the 7 cases in which no organism or inclu- sion bodies were present and in the 8 cases in which a virus appeared to be the responsible agent, judging by the presence of epithelial inclusion bodies.

At this stage it is unwarrantable to draw any conclusions as to greater clinical susceptibility of the different varieties of ophthalmia neonatorum to penicillin, but it is clear that neither the occasional failures nor relapses are explicable in terms of bacterial morphology.

\section{Mode of Use}

For the present something like a 5-stage system is in use :

1. On admission a swab is taken for smear and culture and the eye is irrigated with half-normal saline at room temperature. A drop of adrenaline 1 in 1,000 is instilled and a scraping is taken from the palpebral conjunctiva for examination for the presence of inclusion bodies.' Gutt. atropin. sulph. $1 \%$ are instilled if the cornea is involved.

Any pus that may have accumulated is wiped away with moist pledgets of cotton-wool, and one drop of penicillin in a concentration of 2,500 units per c.cm. is instilled. The baby is now returned to its cot.

3. The instillation of penicillin is continued every 5 minutes until there is no discharge. Irrigation is not needed, as pus does not form to any extent; such thin mucoid discharge (with a yellowish tinge from the admixture of penicillin) as is present can be ignored, or, if it clings to the lid margin, wiped away with moist pledgets of cotton-wool. Generally half an hour to three hours' treatment (6 to 30 applications) is necessary before the eye is dry. This part of the treatment requires the full-time attention of the nurse.

4. When there is no longer any discharge the instillation of penicillin is continued at half-hourly intervals. At this stage the conjunctiva rapidly assumes a normal appearance. When all swelling and tendency to moistness have disappeared-and this generally involves treatment for about 6 to 12 hours-penicillin therapy is continued to consolidate the clinical cure.

5. Penicillin is now instilled hourly for 12 hours and 2-hourly for a further 24 hours.

Penicillin is well tolerated by the infant eye; occasionally a mild transitory flushing of the conjunctiva is observed. (In the present series-as in the previous one-no complications of any kind have been observed, but in a case treated subsequent to those recorded here there was an instantaneous and marked swelling of the conjunctiva and lids on the instillation of penicillin in the form of a lamella; the swelling subsided within 12 hours, the child having in the meantime been put on sulphamezathine treatment.)

\section{Comparison with General Sulphonamide Therapy}

It is likely that general sulphonamide therapy of ophthalmia neonatorum is already obsolete as a routine procedure. The results obtained by the intensive application of penicillin locally are almost as strikingly superior to those obtained by sulphonamide therapy as these in turn were over the older methods. The reduction of the duration of treatment from weeks by the older methods to days by the sulphonamides is paralleled by the reduction of treatment from several days by the sulphonamides to as many hours by penicillin. Should it prove possible to standardize penicillin therapy to a less exacting routine than is required at present, an ideal method of treatment, free from the disadvantages of systemic medication, will indeed be achieved.

\section{Summary}

Local therapy by penicillin in a concentration of 2,500 units per c.cm. proved effective in 21 out of 22 cases of ophthalmia neonatorum reported previously.

In a further series of 38 cases reported here, 2 cases failed to respond.

Twenty-five of 38 cases had been treated by intensive application of penicillin (drops instilled every 5 minutes). The results were better than those obtained by the instillation of penicillin at halfhourly intervals (as in the 22 cases reported previously) or at hourly intervals (as in 13 cases in the present series).

The 25 cases treated intensively included the 2 cases that showed no response and 5 cases that relapsed after initial clinical cure; 4 of these 5 relapses responded well to a second course of penicillin Of the 18 cases that responded initially to treatment 13 showed clinical cure within 12 hours, and a further 4 within 12 to 24 hours.

Severity of the clinical condition does not appear to affect the duration of treatment: 
Penicillin is effective against all the common causal organisms of ophthalmia neonatorum, including the presumed virus of inclusion blennorrhoea.

Local penicillin therapy is likely to replace general sulphonamide treatment as the method of choice in ophthalmia neonatorum.

Thanks are due to Dr. E. N. Young, of the Southern Group (L.C.C.) Laboratories, for her painstaking bacteriological examinations, and to Dr. Olga Blum, Dr. Rela Bartfeld, the Matron, and Sister Condon, of White Oak Hospital, for their collaboration. I am indebted to Prof. Sir Alexander Fleming for his interest and help.

Sorsby, A., and Hoffa, E. (1945). British Medical Journal, 1, 114.

\section{PENICILLIN TREATMENT OF HÁND INFECTIONS}

\section{G. J. GrossmarK, M.R.C.S., L.R.C.P.}

\section{W. PLEWES, F.R.C.S.Ed.}

The local use of penicillin in powder and paste (lanette wax form) in the treatment of hand and finger infections has been shown by Florey and Williams (1944) to reduce the time required to clear up sepsis, to diminish pain, and to save an average of nine man-days for each case as compared with controls. In this series. 100 cases of paronychia, pulp whitlow, web-space infections, and suppurative tenosynovitis, in all groups of the population, have been treated with penicillin liquid and cream locally, with results that mainly bear out Florey's findings, but with two main differences-namely, in the results of treatment of osteomyelitis and suppurative tenosynovitis.

\section{Principles of Treatment}

In all cases in which incision was necessary general anaesthesia was used, and a blood-pressure cuff to give a bloodless field. There was no soaking of the fingers or application of heat of any kind. Penicillin was applied either in liquid form or as a cream on a fine-mesh gauze wick. The cream consisted of penicillin mixed with a base-eucerin L.M. The penicillin in this cream was found by our pathologist (Dr. Seiler) to keep its potency for a longer time than the penicillin in lanette wax. The dressings were all done in a special dressing unit; the dresser used the "no-touch technique," and modern methods of prevention of cross-infection were employed. Of the total 100 cases (representing over 500 dressings) the number of times a second organism was grown was 19 . Cultures were taken at the time of operation, and sensitivity to penicillin was tested. Cultures were also taken as a routine at the change of each dressing.

Dressings were done once daily if liquid penicillin was used, or every two days with penicillin cream, since it had previously been found that, although liquid penicillin in an open wound lost its activity in about 24 hours, when cream (penicillineucerin L.M.) was used penicillin activity could still be demonstrated at the end of 48 hours.

Surgical procedures in all groups followed orthodox lines, except in the treatment of acute suppurative tenosynovitis. In this condition previous experience with orthodox incisions was so discouraging that a new technique was used. It was based on the observation that acute pyogenic infection of joints responded dramatically to repeated aspiration of the infected fluid and injection of penicillin liquid. None of these fingers was incised.

\section{Results}

Pulp Infections.-Thirty-six pulp infections arrived at the hospital, having had throbbing fingers for an average of seven days. In every case the organism was a sensitive Staph. aureus (coagulase-positive). In three-quarters of these cases the operation was the usual bilateral incision, and the remaining quarter had either the "hockey-stick" or the "fish-mouth" incision. None of these cases was treated as an in-patient, nor was any splinting done, and the average number of dressings was six. In about half the cases sloughing was present to an extent that mechanical removal was required, and here the time taken to heal was twice as long as when sloughing was not a feature. The occurrence of sloughing seemed to bear no relation to the length of time before operation. The average number of days to "no growth" was 9, and the period off work 17. All the end-results were good.

Paronychia.-There were 32 cases in this group. In all except four the causative organism was Staph. aureus (the others, Str. pyogenes). Fourteen of these cases had pus under the nail by the time they were first seen, and enough nail was removed at operation to allow access of the penicillin cream to all the infected area. The average time before being seen at hospital was 10 days. In just over half the operations it was found necessary to open the finger on both sides. In the remainder one lateral incision sufficed. On one occasion the pus could be aspirated through a needle, followed by penicillin injection through the same needle. Dressings were done at 48-hour intervals, and on an average four dressings were required. For all this group the average number of days off work was 12 ; the average number of days before a sterile culture was obtained was 5 . The final result was satisfactory in every case.

Web-space Infections.-This group contained 23 cases, and the average time before treatment was 11 days. The operation consisted of an incision between the distal crease of the palm distally to the beginning of the web. Fourteen of these cases were infected by a sensitive Staph. aureus. The average time to " no growth" was 9 days and off-work 19 days; each case required on an average seven dressings. Sloughing as a prominent feature was present only once, and chemotherapy was used on two of four patients admitted (because of lymphangitis or adenitis).

Tendon-sheath Infections.--There were nine patients who had an acute suppurative tenosynovitis affecting one of the fingers for an average of four days, the organism in six cases being Staph aureus, in three Str. pyogenes. None of these fingers was incised; instead, pus from the sheath was aspirated opposite the proximal phalanx, and after aspiration of all that was possible 1 or $2 \mathrm{c.cm}$. of penicillin was injected through the same needle. The puncture wound was then sealed off with collodion. No splinting was done, and all of these patients were treated as in-patients; the first five cases were given sulphathiazole for five or six days. Active movements were encouraged from the first, and the relief of pain was dramatic in all but one case. This case failed to respond to treatment, and amputation was necessary because of a fulminating infection of the whole finger. In seven cases the results were perfect after one, two, three, or four punctures of the sheath (at 48hour intervals). One patient apparently had a perfect result after four treatments (aspiration of pus and injection of liquid penicillin), but a month later had developed a slight flexion deformity of the finger. This has remained stationary, and the finger can be used. The average stay in hospital for this group was seven days, and the time off work 13 days. There was no difference in the clinical course when sulphathiazole was used, and the last four cases (all perfect results) were not given systemic chemotherapy.

Osteomyelitis.-Another group, comprising cases of osteomyelitis, were tried with local penicillin, and although one could get negative cultures in a time not appreciably longer than with the above groups, the clinical course of the disease did not seem to be affected. The results of treatment were uniformly bad. It ' is difficult to report accurately on this group because, first, amputation was often carried out relatively early; secondly, 'some of the cases were sent elsewhere for $x$-ray therapy ; and, finally, some are still unhealed.

\section{Comments}

Early on it was realized that removal of slough helped considerably, and the results show this to be true. After trying trypsin and pyruvic acid it was felt that simple excision with a pair of sharp nail scissors was not only quicker but usually more effective.

When this research was started penicillin at a strength of 50 units per c.cm. was used for a few weeks. Subsequently the strength varied from 50 to 2,000 units per c.cm. From our analysis the strength of the penicillin employed had no effect on the result. 